\title{
APLIKASI PUPUK DAN MULSA JERAMI PADA TANAMAN KEDELAI TERHADAP SERANGAN HAMA DAN PRODUKSI
}

\section{THE EFFECT OF FERTILIZER AND STRAW MULCH APPLICATION TO PEST ATTACKS AND PRODUCTION OF SOYBEAN}

\author{
J. Rimbing, J. Pelealu, dan D. Sualang*) \\ "Fakultas Pertanian, Universitas Sam Ratulangi, Manado
}

\begin{abstract}
The research was arranged in a randomized block design (RBD), with 10 treatments and 3 replications. To get the active insects pests, net sweepings were done for the flying insects, while other pests were observed directly on the plants. Collecting data of plant damages were made by systematic diagonal lines, except for viruses, census was conducted on each experimental plot. The results of this experiment documented 12 species of insect pests attacking soybean plants. Soybean pest populations were relatively low, except for Aphis glycine that was quite high. In all treatments, plant damage caused by sucking pest Piezodorus sp and Riptortus linearis were relatively low of $1.53 \%$ to $1.94 \%$; it indicated an insignificant effect to decline the production. Crop damages by virus showed a significant effect. The lowest virus attacks found on compost of 5 tons per ha with 43 plants infected per treatment, the highest virus attack showed on combination of 5 tons compost per ha + inorganic fertilizer + mulch, in which there were 274 infected plants per treatment. Apparently virus attacks gave impact on soybean production. The highest production were documented on treatment of 5 tons compost per ha with production of 0.55 tons per ha, while the lowest production was found on combination of 5 tons compost per ha + inorganic fertilizer + mulch, in which the production was 0.22 tons per ha.
\end{abstract}

Keywords: fertilizer, mulch, insect pest, production

\section{ABSTRAK}

Penelitian ini disusun dalam rancangan acak kelompok (RAK), dengan 10 perlakuan dan diulang 3 kali. Untuk mendapatkan jenis serangga hama aktif terbang dilakukan penyapuan dengan jaring serangga, sedangkan hama lain diamati secara langsung pada tanaman. Pengambilan data kerusakan oleh hama dilakukan menurut garis diagonal secara sistemmatik, kecuali serangan virus dilakukan secara sensus pada setiap petak percobaan. Hasil percobaan ini telah ditemukan 12 jenis serangga hama yang menyerang tanaman kedelai. Populasi hama kedelai masih tergolong rendah, kecuali hama Aphis glycine cukup tinggi. Kerusakan tanaman oleh hama pengisap Piezodorus sp dan Riptortus linearis masih tergolong rendah pada semua perlakuan $1,53-1,94 \%$, sehingga belum memberikan pengaruh nyata terhadap penurunan produksi. Pengaruh kerusakan tanaman oleh virus memberikan pengaruh yang nyata. Serangan virus yang terendah ditemukan pada pupuk kompos 5 ton per ha 43 tanaman per perlakuan, serangan virus tertinggi pada pupuk kompos 5 ton/ha+ pupuk anorganik + Mulsa 274 tanaman terserang per perlakuan. Serangan virus berdampak terhadap produksi kedelai, produksi yang tertinggi terdapat pupuk kompos 5 ton per ha 0,55 ton/ha, sedangkan produksi terendah ditemukan pada pupuk kompos 5 ton/ha + pupuk anorganik + mulsa 0,22 ton per ha.

Kata kunci: pupuk, mulsa, serangga hama, produksi

Eugenia Volume 21 No. 1 Pebruari 2015 


\section{PENDAHULUAN}

Produksi kedelai untuk Indonesia masih tergolong rendah rata-rata 8,7 ton/ha. Sementara produksi kedelai pada tahun 2013 hanya mencapai 800.000 ton, tetapi kebutuhan nasional kedelai mencapai 2,5 juta ton (Anonim, 2012). Dengan adanya kekurangan kedelai sebagai kebutuhan nasional, maka pemerintah Indonesia harus mengimport kedelai untuk memenuhi kebutuhan masyarakat. Sudah tentu banyak faktor yang menyebabkan produksi kedelai masih tergolong rendah yakni benih, sanitasi, tanah yang kurang produktif, iklim dan terutama adanya serangan hama dan penyakit tanaman yang telah menimbulkan kerusakan pada tanaman kedelai (Anonim, 1999; Sembel, dkk., 2000).

Penelitian yang dilakukan di Bolmong Sulawesi Utara tahun 1989 menunjukkan bahwa kerusakan hama pengisap polong kedelai, $N$. virudala, $R$. linearis, dan Piezodorus sp. pada tiga varietas kedelai tidak berpengaruh nyata, tingkat kerusakan hama pengisap polong mencapai $28,5 \%$ (Sembel dkk., 1989). Hama N. virudala, R. linearis, dan Piezodorus sp merupakan hama utama tanaman kedelai di Indonesia (Anonim, 1999). Marwoto dkk. (1999) melaporkan bahwa kehilangan hasil akibat serangan hama-hama kedelai dapat mencapai $80 \%$, bahkan sampai puso bila tidak dilakukan pengendalian.

Pengendalian serangga hama pada tanaman kedelai oleh petani masih sangat bergantung pada pestisida. Penyemprotan insektisida yang dilakukan oleh petani $6-8$ kali untuk satu musim tanam, bahkan seringkali frekwensi penyemporotan melebihi dari 8 kali (Sembel, dkk., 2000). Insektisida yang digunakan dalam mengendalikan hama kedelai di Sulawesi Utara adalah Dursban 20 EC, Ambush 2 EC, Marshal 200 EC dan Proclaim 5 SG. Purwata dan Rauf (2000) melaporkan bahwa insektisida berpengaruh terhadap penurunan populasi musuh-musuh alami pada tanaman kedelai, sedang hama sulit tertekan oleh insektisida BPMC, Profenofos, Deltametrin yang diaplikasikan sebanyak 3 aplikasi.

Pemberian mulsa jerami merupakan salah satu faktor untuk konservasi musuh alami pada pertanaman kedelai, karena jumlah jenis dan kelimpahan parasitoid lebih tinggi tanpa mulsa jerami. Perlakuan mulsa jerami ditemukan 14 jenis parasitoid yang cendrung lebih tinggi dibanding dengan tanpa sanitasi 13 dan sanitasi 11 jenis. Proporsi parasitoid tertinggi adalah parasitoid Telenomus sp yang merupakan parasitoid telur pada hama pengisap polong kedelai. Proporsi parasitoid Telenomus sp pada perlakuan tanpa sanitasi $31,80 \%$, mulsa jerami $27,50 \%$, dan sanitasi $21,43 \%$. Pada perlakuan mulsa jerami ditemukan proporsi parasitoid telur Encyrtidae $22,50 \%$, cendrung lebih tinggi dibanding tanpa sanitasi $9,23 \%$, sanitasi $12,30 \%$ ). (Rimbing $d k k$., 2007) Parasitoid telur Encyrtidae memarasit telurtelur hama pengisap polong kedelai (Kalshoven, 1981; Wardani, 2001)

Peranan mulsa jerami, selain meningkatkan jenis dan kelimpahan populasi musuh alami dapat pula meningkatkan produksi tanaman. Tanaman wortel dengan pemberian mulsa jerami diameter umbi pada perlakuan mulsa jerami 4,59 $\mathrm{cm}$, dan berat umbi $73,00 \mathrm{gr}$, sedangkan pada kontrol diameter umbi $3,50 \mathrm{~cm}$, dan berat umbi hanya $52 \mathrm{gr}$ (Fausan, 2002). Di Jawa Tengah, Klaten produksi jagung hibrida dapat mencapai 1215 ton/ha pada perlakuan mulsa organik kapulog, kunyit, kimpul, dan jerami, sedangkan kontrol hanya menghasilkan 10,55 ton/ha. Kenaikan produksi jagung berkisar antara 21,25 - 43,13\% (Sugiyarto dan Anggawulan, 2002).

Terdapat beberapa manfaat kompos bagi tanaman, yaitu memberikan nutrisi bagi tanaman, memperbaiki struktur tanah, meningkatkan kapasitas tukar kation, menambah kemampuan tanah untuk menahan air, meningkatkan aktifitas biologi tanah, mampu meningkatkan $\mathrm{Ph}$ tanah asam, dan tidak menimbulkan masalah lingkungan (Sutanto, 2000; Sugito, 2002). Pemberian pupuk kompos berpengaruh terhadap kerusakan tanaman sebagaimana yang dilaporkan oleh Senewe $d k k$. (2005) bahwa pemberian kompos sebanyak 10 ton/ha dapat menekan kerusakan tunas oleh hama penggerek batang padi (Scirpophaga sp). Tanaman padi sawah yang diberi pupuk kompos pada saat tanam tingkat kerusakan tunas oleh penggerek batang padi rata-rata 1,2 tunas per 10 rumpun, 
sedangkan tanpa pupuk kompos rata-rata tingkat kerusakan tunas 2,7 per 10 rumpun. Engka (2006) melaporkan bahwa penggunaan pupuk kompos 12,0 ton/ha memberikan pengaruh yang baik terhadap produksi gabah kering 6,0 ton /ha lebih tinggi dibanding perlakuan pupuk kompos 7,5 ton/ha, berat kering gabahnya hanya 5,1 ton /ha.

Penelitian bertujuan untuk mengetahui pengaruh pemberian pupuk kompos, anoragnik, dan kombinasi pupuk dengan menggunakan mulsa jerami terhadap jenis hama, kerusakan tanaman dan produksi .

\section{METODE PENELITIAN}

Penelitian dilaksanakan di Kecamatan Poigar Kabupaten Bolaang Mongondow. Daerah ini merupakan salah satu sentra produksi tanaman kedelai untuk Bolaang Mongondow. Waktu pelaksanaan penelitian selama 6 bulan, mulai dari persiapan sampai panen.

Percobaan ini disusun dalam rancangan acak kelompok (RAK) terdiri dari 10 perlakuan dan diulang sebanyak 3 kali, sehingga dalam percobaan ini diperoleh 30 petak percobaan (10 perlakuan $\times 3$ ulangan $=30$ petak). Adapun perlakuan dalam percobaan ini adalah sebagai berikut: Pupuk kompos 3 ton/ha; Pupuk kompos 5 ton/ha; Pupuk anorganik (Urea $(75 \mathrm{~kg} / \mathrm{ha}$, TSP (100 kg/ha, dan $\mathrm{KCL} 100 \mathrm{~kg} / \mathrm{ha}) ;$ Pupuk kompos 3 ton/ha + anorganik; Pupuk kompos 5 ton/ha + anorganik; Pupuk anorganik + mulsa jerami; Pupuk kompos 3 ton/ha + mulsa jerami; Pupuk kompos 5 ton/ha + mulsa jerami; Pupuk kompos 3 ton/ha + pupuk anorganik + mulsa jerami; Pupuk kompos 5 ton/ha+ pupuk anorganik + mulsa jerami

Petak percobaan untuk setiap perlakuan berukuran $2 \times 5$ meter, dengan jarak tanam $40 \times 15$ $\mathrm{cm}$. Setiap lubang hanya ditumbuhi 2 tanaman, sehingga jumlah tanaman dalam 1 petak diperoleh sebanyak 156 rumpun. Varietas yang digunakan dalam percobaan ini adalah Mahameru.

\section{Pengambilan Data}

Pengambilan data untuk jenis serangga hama dilakukan pengamatan langsung pada pertanaman kedelai dan pengambilan contoh dengan jaring serangga. Penggunaan jaring serangga dilakukan pada serangga hama pengisap polong kedelai dan serangga yang aktif terbang. Penyapuan dengan jaring serangga pada tanaman kedelai dilakukan sebanyak 5 ayunan per petak. Pengambilan data jenis serangga hama dilakukan mulai dari 14 hst sesudah tanam sampai 80 hst (hari sesudah tanam). Serangga hama yang ditemukan baik dalam bentuk larva, nimfa dan imago dibuat koleksi untuk keperluan identifikasi.

\section{Kerusakan Tanaman Oleh Hama Tanaman}

Untuk mendapatkan data kerusakan tanaman oleh serangga hama maka diambil contoh sebanyak 14 tanaman/per petak. Jadi dalam percobaan ini untuk mendapatkan data kerusakan tanaman kedelai pada 30 petak diperlukan sebanyak 420 tanaman. Contoh tanaman kedelai yang diamati dilakukan menurut garis diagonal. Pengambilan contoh tanaman menurut garis diagonal dilakukan secara sistemmatik, dimana setiap garis diagonal diambil 7 tanaman.

Polong yang terserang oleh hama pengisap polong kedelai ditandai dengan polong hampa dan biji berkeriput. Untuk mengetahui secara pasti polong menjadi hampa atau gugur disebabkan oleh hama pengisap polong dilakukan pengamatan di laboratorium. Polong yang hampa ditandai dengan adanya bekas tusukan pada polong oleh hama.

Formula digunakan untuk mengetahui jumlah polong yang hampa adalah sebagai berikut :

$$
\text { I = } \frac{\text { Jumlah polong yang hampa,gugur/tanaman }}{\text { Jumlah polong yang diamati /tanaman }} \times 100 \%
$$

Kerusakan tanaman yang disebabkan oleh adanya serangan virus melalui $A$. glycine dilakukan secara sensus pada setiap petak. Serangan virus pada tanaman kedelai ditandai dengan adanya perubahan warna daun menjadi hijau kekuningan dan pertumbuhan menjadi kerdil. Pengambilan data dengan adanya serangan virus dimulai pada umur $21 \mathrm{hst}$, kemudian dilakukan secara kontinu dengan interval waktu 1 minggu sampai 80 hst. 


\section{Analisis Data}

Untuk mengetahui pengaruh pupuk kompos, pupuk anorganik dan mulsa jerami baik dilakukan analisis keragaman (ANOVA), kemudian dilanjutkan pada uji beda nyata terkecil (BNT), bila diantara perlakuan berpengaruh nyata.

\section{HASIL DAN PEMBAHASAN}

\section{Jenis Hama Tanaman Kedelai}

Serangga hama yang menyerang tanaman kedelai sejak umur 14 hst (hari sesudah tanam) sampai 80 hst yang dilakukan pengamatan langsung maupun mengunakan jaring serangga telah ditemukan 12 jenis. Jenis serangga hama yang ditemukan adalah Laprosema indicata, Empoasca sp.,Patanga sp., Ophiomyia phaseoli, Acrida sp., Oxya sp. Helicoverpha armigera, Valanga sp., Aphis glycine, Spodoptera litura, Piezodrus sp., Riptortus linearis, dan Etiella. zinckenella. Hasil pematauan di lapangan diperoleh bahwa populasi yang cukup tinggi adalah $A$ glycine, Piezodrus sp., Riptortus linearis dan $E$. zinckenella. Keempat hama ini dapat ditemukan pada semua petak percobaan, sedangkan serangga hama lainnya hanya ditemukan pada petak tertentu dalam satu perlakuan. Jumlah populasi hama pengisap polong 1-3 ekor, sedangkan hama lainnya menyerang bagian daun 0-2 individu per petak. Terdapat beberapa jenis serangga hama yang belum ditemukan dalam percobaan ini, diantaranya Chrysodexis sp. Jenis serangga hama yang tanaman kedelai di Indonesia berjumlah 29 jenis (Afifah, 2009; Anonim, 2007). Adanya perbedaan topografi, iklim, dan ekosistem tanaman kedelai dapat mempengaruhi terhadap jenis hama yang menyerang tanaman kedelai. Hama $H$. armigera dapat ditemukan pada tanaman kedelai dalam percobaan ini, karena dalam ekosisten tanaman pertanian di lokasi penelitian ditemukan tanaman jagung, dimana hama ini merupakan hama utama pada jagung dan di wilayah ini tanaman jagung dilakukan setiap musim tanam sehingga hama ini tersedia inang sebagai sumber makanannya.

Dalam pengamatan di lapangan menunjukkan bahwa jenis serangga hama yang menyerang tanaman kedelai ditemukan fase pertumbuhan vegetatif dan generatif. Serangga yang ditemukam pada fase vegetatif diantaranya $O$. phaseoli dan $S$. litura, sedangkan yang ditemukan menyerang pada generatif dan tidak ditemukan pada fase vegetatif, yakni Piezodrus sp., $R$. linearis $H$. armigera dan E. zinckenella. Keempat jenis serangga menyerang bagian polong kedelai. Untuk jenis serangga hama yang ditemukan menyerang fase vegetatif dan generatif adalah $L$. indicata, Empoasca sp.,Patanga sp., Valanga sp., Acrida sp., Oxya sp. dan A. glycine. Jenis hama ini dapat ditemukan pada kadua fase pertumbuhan tanaman kedelai disebabkan hama tersebut menyerang bagian daun dan pucuk tanaman. Kerusakan tanaman oleh hama tersebut belum menimbulkan kerugian yang berarti bagi tanaman kedelai.

\section{Serangan Hama Kedelai}

Dalam percobaan ini untuk mengetahui serangan hama pada tanaman kedelai dibatasi pada hama Piezodrus sp. dan $R$. linearis yang menyerang bagian polong dan $A$. glycine sebagai vektor virus. $H$. armigera menyerang polong, tetapi serangan sangat rendah dibandingkan dengan hama Piezodrus sp. dan $R$. linearis, kerusakan polong oleh $\mathrm{H}$. armigera tidak dihitung. Demikian pula hama lainnya seperti $L$. indicata, Empoasca sp.dan ,Patanga sp., tidak dihitung tentang kerusakan tanaman, karena hama tersebut hanya menyerang bagian daun dan tidak menimbulkan kerusakan yang berarti bagi tanaman kedelai dan populasinya sangat rendah. Berbeda dengan hama Piezodrus sp.,dan $R$. linearis meskipun populasi masih tergolong rendah, tetapi kerusakan pada tanaman memberi pengaruh nyata terhadap produksi. Hama Piezodrus sp. dan $R$. linearis mengisap polong yang masih muda pada saat pembentukan biji, akibatnya polong menjadi hampa, kemudian gugur.

Serangan hama Piezodrus sp. dan $R$. linearis yang banyak ditemukan adalah polong telah menjadi hampa, sedangkan serangan pada biji menjadi berkeribut sangat kurang. Hasil analisis statistik menunjukkan bahwa persentase serangan hama pengisap polong kedelai tidak berbeda nyata diantara perlakuan. Hal ini dimungkinkan, karena populasinya tergolong rendah dan populasi hampir 
menyebar merata pada semua petak perlakuan. Populasi hama pengisap setelah dilakukan pengambilan contoh dengan jaring serangga berkisar 1 3 ekor per 5 ayunan per petak. Rendahnya populasi hama pengisap polong, menyebabkan persentase serangan hama pada polong kedelai tergolong rendah, sehingga tidak nampak perbedaan persentase kerusakan polong pada semua perlakuan. Penelitian Taroreh (1995) di Kabupaten Bolaang Mongondow bahwa populasi hama $R$. linearis pada petak kontrol lebih tinggi dibandingkan dengan perlakuan insektisida, dimana petak kontrol populasinya 11,0 ekor/ 14 rumpun, sedangkan perlakuan insektisida Azodrin 6,0 ekor/14 rumpun dan paling rendah insektisida Dursban 5,0 ekor/14 rumpun.

Meskipun tidak terdapat perbedaan yang nyata serangan hama pengisap polong kedelai setelah dilakukan analisis statistik, tetapi secara visual masih dapat dibedakan serangan hama tertinggi dan terendah. Data tingkat serangan hama Piezodrus $\mathrm{sp}$. dan $R$. linearis pada polong kedelai dapat diikuti pada Tabel 1.

Serangan hama pengisap polong kedelai menyebar merata pada semua perlakuan, dan tidak ditemukan perbedaan yang nyata diantara perlakuan. Persetase serangan hama yang tertinggi ditemukan pada perlakuan kombinasi pupuk kompos 3 ton/ha + anorganik tanpa mulsa 1,98 \%, sedangkan serangan paling rendah pada perlakuan pupuk kompos 3 ton/ha tanpa mulsa 1,53\%. Meskipun terdapat pengolongan serangan hama pengisap polong yang rendah dan tertinggi, tetapi dalam percobaan ini belum diketahui secara pasti perbedaan berat biji masing-masing perlakuan, akibat serangan hama pengisap polong. Berbeda dengan hama penggerek polong terdapat perbedaan di antara perlakuan dimungkin karena kerusakan polong cukup tinggi (Rimbing, dkk., 2010)

Dalam percobaan ini telah ditemukan 2 jenis parasitoid yang memarasit telur-telur hama pengisap polong yakni Ooncyrtus sp., Telenomus sp. Hasil penyapuan dengan jaring serangga telah ditemukan populasi parasitoid 1-2 ekor per 10 kali ayunan ganda per perlakuan. Diduga serangan hama pengisap polong kedelai tergolong rendah mungkin disebabkan adanya parasitoid telur. Rimbing, dkk. (2007) melaporkan bahwa kelimpahan populasi kedua parasitoid menjadi tinggi dengan adanya mulsa jerami. Secara kumulatif kedua parasitoid telur tersebut pada perlakuan mulsa jerami proporsinya adalah $54,30 \%$, lebih tinggi dari tanpa sanitasi 40,03\%, dan sanitasi 33,73. Dengan adanya mulsa jerami parasitoid dapat berkembang dengan baik, dimana mulsa jerami digunakan parasitoid sebagai tempat berlindung dan kopulasi. Diduga peran parasitoid telur cukup berarti karena mampu menekan populasi hama pengisap polong menjadi rendah. Jadi dengan adanya mulsa jerami mungkin berpengaruh terhadap kelimpahan parasitoid telur Ooncyrtus $s p$ dan Telenomus sp, sehingga populasi hama pengisap kedelai tertekan. Meskipun mulsa jerami berpengaruh postif terhadap populasi parasitoid telur, bila disuatu wilayah tidak ditemukan parasitoid tersebut akan berdampak positif terhadap peningkatan populasi hama pengisap polong kedelai.

Tabel 1. Persentase Serangan Hama Pengisap Polong Kedelai

(Table 1. Percentage of Suction Pods Soybean Pest Attacks)

\begin{tabular}{llc}
\hline No & \multicolumn{1}{c}{ Perlakuan } & Persentase Serangan (\%) \\
\hline 1 & Pupuk kompos 3 ton/ha & 1,53 \\
2 & Pupuk kompos 5 ton/ha & 1,89 \\
3 & Pupuk anorganik & 1,65 \\
4 & Pupuk kompos 3 ton/Ha + mulsa & 1,93 \\
5 & Pupuk kompos 5 ton/ha + mulsa & 1,87 \\
6 & Pupuk kompos 3 ton/ha + pupuk anorganik & 1,98 \\
7 & Pupuk kompos 5 ton/ha + pupuk anorganik & 1,57 \\
8 & Pupuk kompos 3 ton/ha + pupuk anorganik + Mulsa & 1,90 \\
9 & Pupuk kompos 5 ton/ha + pupuk anorganik + Mulsa & 1,94 \\
10 & Pupuk anoganik + Mulsa & 1,82 \\
\hline
\end{tabular}


Kehadiran hama kutu daun A. glycine telah mempengaruhi pertumbuhan tanaman kedelai menjadi terhambat. A. glycine mulai muncul pada umur tanaman kedelai 14 hst sampai menyelang panen hama tersebut masih nampak, tetapi populasinya sangat rendah. Dalam percobaan ini kelimpahan populasi cukup tinggi, hal ini diketahui adanya pertumbuhan tanaman menjadi terhambat dan kerdil serta daun berubah menjadi warna hijau kekuningan. Kerusakan tanaman kedelai oleh $A$. glycine mengisap daun atau pucuk tanaman, sehingga pengaruh terhadap tanaman kurang berarti bila dibandingkan dengan hama lain yang memakan daun seperti $L$. indicate. Kehadiran hama pada tanaman kedelai menjadi penting, karena $A$. glycine sebagai vektor virus. Hasil menunjukkan bahwa serangan virus banyak terjadi pada pemberian mulsa dibandingkan dengan tanpa mulsa. Besar serangan virus disebabkan pada perlakuan mulsa sangat dipengaruhi kelimpahan populasi $A$. glycine. Diduga kelimpahan populasi $A$. glycine pada perlakuan mulsa lebih tinggi dibandingkan dengan tanpa mulsa. Pemberian mulsa pada pertanaman kedelai menyebabkan terjadi perubahan mikrohabitat, terutama dipermukaan tanah. perubahan tersebut berpengaruh positif terhadap serangga (Smith \& Hammond, 1988). Perubahan mikrohabitat akan berpengaruh iklim mikro pada ekosistem tanaman kedelai yang sesuai bagi perkembangan populasi A. glycine.

Peranan hama kutu daun, $A$. glycine pada tanaman kedelai sebagai vektor virus pada tanaman kedelai. A. glycine sebagai vektor virus pada tanaman kacang-kacangan, yakni Soybean mosaic virus, Soybean yellow mosaic virus, bean yellow mosaic, soybean dwart virus dan peanut stripe virus. Adanya serangan virus dipengaruhi oleh kelimpahan populasi, kelimpahan populasi dipengaruhi keadaan cuaca (Anonim, 2007). Dengan adanya serangan virus pada tanaman kedelai telah mempengaruhi terhadap pertumbuhan menjadi kerdil dan akan berdampak produksi kedelai. Data serangan virus pada tanaman kedelai untuk masing-masing perlakuan dapat diikuti pada tabel 2.

Serangan virus mulai nampak pada tanaman kedelai berumur 21 hst. Pertumbuhan tanaman memasuki fase pengisian polong. mulai terhambat oleh serangan penyakit virus. Tanaman yang terserang virus menghasilkan jumlah polong yang tergolong rendah dan daunnya lebih cepat mengering dari pada tanpa serangan virus. Dari data menunjukkan bahwa serangan virus yang tertinggi ditemukan pada perlakuan dengan pupuk anorganik. Tanaman yang diberi pupuk urea yang berlebihan akan mengakibatkan peningkatan kandungan air sehingga tanaman lebih sukulen dan mudah terserang hama dan penyakit tanaman (Mills and Jones, 1971). Serangan virus ada kaitan dengan kelimpahan populasi $A$. glycine, sudah tentu populasi yang tinggi akan menimbulkan serangan penyakit virus. Pemberian urea dapat meningkatkan kelimpahan populasi $A$. glycine, hal ini dapat diketahui dengan peningkatan serangan virus pada tanaman kedelai pada perlakuan yang diberi pupuk urea. Tanaman yang diberi fosfat 13$46 \mathrm{~kg} \mathrm{P}_{2} \mathrm{O}_{2} /$ ha tanpa urea dapat menekan populasi Aphis sp dan menambah panjang trikomata dan ketebalan kutikula (Brotodjo dan Estyanti, 2009). Jumlah polong yang dihasilkan oleh tanaman terserang virus berkisar 20-30 polong per tanaman.

Besarnya serangan penyakit virus pada percobaan ini, karena terjadi musim panas sejak umur 14 hst sampai panen. Populasi $A$. glycine berpengaruh positif terhadap musim panas, sehingga terjadi peningkatan populasi A. glycine. Adanya kelimpahan populasi sudah tentu akan berdampak muncul penyakit virus. Marwoto $d k k$. (1999) mengemukakan bahwa pada cuaca yang panas pada musim kemarau sering menyebabkan populasi hama kutu daun ini menjadi tinggi. Dengan adanya peningkatan populasi hama $A$. glycine, hal ini berdampak pada penyebaran penyakit virus pada tanaman kedelai. Oleh karena itu untuk menekan populasi hama $A$. glycine sebaiknya dilakukan pada umur 3-4 minggu sesudah tanam. 
Tabel 2. Jumlah Tanaman Terserang Virus Pada Setiap Perlakuan

(Table 2. Number of Esophageal Plant Virus On Any Treatment)

\begin{tabular}{clc}
\hline No. & \multicolumn{1}{c}{ Perlakuan } & Jumlah Tanaman Terserang Virus \\
\hline 1. & Pupuk kompos 3 ton/ha Tanpa Mulsa & 59 \\
2. & Pupuk kompos 5 ton/ha Tanpa Mulsa & 43 \\
3. & Pupuk anorganik & 67 \\
4. & Pupuk kompos 3 ton/ha +pupuk anorganik & 47 \\
5. & Pupuk kompos 5 ton/ha + pupuk anorganik & 71 \\
6. & Pupuk kompos 3 ton/ha + mulsa & 79 \\
7. & Pupuk kompos 5 ton/ha + mulsa & 106 \\
8. & Pupuk anorganik dengan Mulsa (H) & 102 \\
9. & Pupuk Kompos 3 ton /ha + pupuk anorganik + Mulsa & 119 \\
10. & Pupuk Kompos 5 ton/ha + Pupuk Anorganik + Mulsa & 274 \\
\hline
\end{tabular}

Sebagaimana yang tercatum pada Tabel 2. bahwa serangan penyakit virus tertinggi pada perlakuan dengan mulsa jerami dibanding dengan tanpa mulsa. Diduga mikroklimat pada pertanaman kedelai yang diberi mulsa lebih disukai oleh hama A. glycine, sehingga terjadi peningkatan populasi $A$. glycine. Dengan adanya mulsa jerami menyebabkan kelembaban pada perlakuan mulsa menjadi tinggi, dan hal ini mungkin berpengaruh terhadap populasi A. glycine. Pemberian mulsa jerami pada tanaman kedelai menyebabkan terjadi penutupan tanah dan semakin kecil terjadi pertukaran panas dari tanah ke udara. Rohim (1999) mengemukakan bahwa tanah yang diberi mulsa jerami dapat menurunkan suhu tanah. Suhu tanah terendah dicapai pada pemberian mulsa jerami, pada siang hari jam 13.00 suhu tanah yang diberi mulsa jerami $30,70^{\circ} \mathrm{C}$, sedangkan tanpa mulsa, suhu siang hari mencapai $33,0^{\circ} \mathrm{C}$.

\section{Berat Biji Kedelai}

Kebanyakan biji kedelai telah digerek oleh hama penggerek polong, sedangkan biji berkeriput sangat kurang yang diserang oleh hama pengisap polong. Persentase serangan yang masih tergolong ringan terdapat pada pupuk kompos 51,2 \%, sedangkan persentase yang tergolong berat pada pupuk kompos + pupuk anorganik + mulsa 92,9 \% (Rimbing, dkk., 2010). Biji kedelai yang telah digerek sangat berpengaruh terhadap produksi dalam percobaan ini, karena dapat mempengaruhi berat kering biji kedelai.

Hasil penimbangan bahwa berat biji kedelai yang digerek oleh penggerek polong se- banyak 500 biji hanya menghasilkan $32,04 \mathrm{gr}$, sedangkan biji yang masih utuh menghasilkan berat biji 52,2 gr. Dari hasil menunjukkan bahwa berat biji yang utuh nilai jual lebih besar dibandingkan berat biji yang digerek atau biji berkeriput. Jadi dengan adanya gerekan larva pada biji kedelai telah berpengaruh terhadap penurunan produksi. Kehilangan akibat biji kedelai yang digerek oleh larva penggerek polong dapat mencapai $38,6 \%$. Hasil analisis statistik berat biji kedelai terdapat perbedaan yang nyata diantara perlakuan. Data produksi kedelai untuk masing-masing perlakuan dapat diikuti pada tabel 3.

Rata-rata produksi kedelai yang ditemukan pada perlakuan tanpa mulsa cendrung lebih tinggi dibandingkan dengan menggunakan mulsa jerami. Pada perlakuan dengan menggunakan mulsa jerami serangan hama penggerek polong kedelai tergolong tinggi dibandingkan dengan tanpa mulsa. Serangan hama penggerek polong tergolong rendah adalah pupuk kompos tanpa mulsa (Rimbing, dkk., 2010). Demikian pula serangan virus yang terendah terdapat pada perlakuan pupuk kompos tanpa mulsa, hal ini berdampak terhadap produksi kedelai menjadi tinggi diantara perlakuan. Produksi kedelai tertinggi terdapat pada perlakuan pupuk kompos 5 ton/ha; 0,55 ton/ha, kemudian diikuti pupuk kompos 3 ton /ha tanpa mulsa jerami 0,52 ton/ha, dan paling rendah produksinya terdapat perlakuan kombinasi pupuk kompos 5 ton/ha + pupuk anorganik + mulsa jerami 0,22 ton/ha. Dalam percobaan penurunan produksi yang nyata disebabkan oleh hama pengisap polong, penggerek polong dan adanya serangan virus. 
Tabel 3. Rata-rata Produksi Tanaman Kedelai Pada Masing-masing Perlakuan.

(Table 3. Average Crop Soybean Production In Each Treatment)

\begin{tabular}{llc}
\hline No. & \multicolumn{1}{c}{ Perlakuan } & Produksi ton/ha \\
\hline 1. & Pupuk kompos 5 ton/Ha + Pupuk anorganik + Mulsa & $0,22 \mathrm{a}$ \\
2. & Pupuk kompos 3 ton/Ha + Pupuk anorganik + Mulsa & $0,35 \mathrm{~b}$ \\
3. & Pupuk anorganik + Mulsa & $0,35 \mathrm{~b}$ \\
4. & Pupuk kompos 5 ton/ $/ \mathrm{Ha}+$ Mulsa & $0.36 \mathrm{~b}$ \\
5. & Pupuk anorganik 3 ton/ha + Mulsa & $0.39 \mathrm{bc}$ \\
6. & Pupuk kompos 5 ton/ $/ \mathrm{Ha}+$ Pupuk anorganik + tanpa Mulsa & $0,41 \mathrm{bcd}$ \\
7. & Pupuk anorganik + tanpa Mulsa & $0.46 \mathrm{bcde}$ \\
8. & Pupuk kompos 5 ton/Ha + Pupuk anorganik + tanpa mulsa & $0,49 \mathrm{cde}$ \\
9. & Pupuk kompos 3 ton/ha + tanpa mulsa & $0,52 \mathrm{de}$ \\
10. & Pupuk kompos 5 ton/ha + tanpa mulsa & $0,55 \mathrm{e}$ \\
\hline
\end{tabular}

BNT $5 \%=0,12$

Dalam percobaan ini, faktor utama yang mempengaruhi produksi kedelai adanya hama penggerek polong dan virus, sehingga produksi yang dicapai dalam percobaan ini hanya mencapai 0,55 ton/ha. Uji beberapa varietas terhadap serangan hama penggerek polong kedelai di Purbalingga (Jawa Tengah) menunjukkan bahwa serangan hama penggerek polong kedelai berkisar $63,7-93,7 \%$ dengan produksi 0,3 ton/ha $-0,8$ ton/ha (Surjana 1993).

\section{KESIMPULAN}

Dalam percobaan ini semua tanaman kedelai terserang virus, tetapi tanaman yang terserang virus tertinggi diperoleh pada perlakuan yang diberi mulsa jerami. Jumlah tanaman yang terserang virus tertinggi ditemjukan pada perlakuan kombinasi pupuk kompos 5 ton/ha + anorganik pada mulsa jerami yakni 274 tanaman per perlakuan. sedangkan yang terendah terdapat pada perlakuan pupuk kompos 5 ton/ha tanpa mulsa 43 tanaman per perlakuan.

Populasi hama pengisap polong $R$. lienaris dan Piezodorus sp masih tergolong rendah sehingga belum berpengaruh nyata terhadap penurunan produksi kedelai. Persentase serangan hama pengisap polong berkisar 1,65 \% - 1,98\%.

Produksi tertinggi ditemukan pada perlakuan pupuk kompos 5 ton/ha tanpa mulsa 0,55 ton biji/ha, dan produksi terendah pada perlakuan pupuk kompos 5 ton + anorganik 0,22 ton biji /ha.

\section{DAFTAR PUSTAKA}

Afifah, L. 2009. Profil Balikabi dan Pengendalian Hama terpadu (PHT) pada Tanaman Kedelai. Departemen dan Proteksi Tanaman, Fakultas Pertanian IPB, Bogor.

Anonim. 1999. Hama Kedelai dan Komponen Pengendalian Hama Terpadu. Balai Penelitian Tanaman Kacang-Kacangan dan Umbi-umbian. Malang

Anonim. 2007. Hama Penyakit dan Masalah Hara Tanaman Kedelai, Identifikasi dan Pengendalianya. Pusat Penelitian dan Pengembangan Tanaman Pangan, Bogor.

Anonim. 2012. Tanaman Pangan. Badan Pusat Statistik Direktorat Jenderal Tanaman Pangan, Departemen Pertanian, Jakarta.

Brotodjo, R.R., Rukmowati dan Estiyanti Satya. 2009. Pemupukan Fosfat untuk Meningkatkan Produksi dan Ketahnanan Tanaman Kedelai terhadap Aphis sp. Seminar Nasional Perlindungan Tanaman. Pusat Kajian Pengendalian Hama Terpadu. Departemen Protek Tanaman. Fakultas Pertanian Institut Pertanian Bogor. Bogor. 
Engka, R. 2006. Pengaruh Pemberian pupuk Kompos Terhadap Produksi dan Kualitas Padi Sawah. Fakultas Pertanian Unsrat

Fausan, A. 2002. Pemanfaatan Mulsa dalam Pertanian Berkelanjutan. Lokakarya Nasional Pertanian Organik Malang

Kalshoven, L.G.E. 1981. The Pests of Crops In Indonesia. PT. Ichtiar Baru Van Hoeve. Jakarta.

Marwoto, Suharsono dan Supriyatin. 1999. Hama Kedelai dan Kompoen Pengendalian Hama Terpadu. Monograf Balitkabi.

Mills, H.A. and J.B. Jones. 1971. Arthropod Pest Associated with Cassava in Brasil. In Hahn S.K., FE. Cavensse (eds) Integrated Pest Management for Tropical Root and Tuber Crop. IITA. P.132-138.

Purwanta, F.X. dan A. Rauf. 2000. Pengaruh Samping Aplikasi Insektisida Terhadap Predator dan Parasitoid pada Pertanaman Kedelai. Buletin Hama Dan Penyakit Tumbuhan. Faklutas Pertanian, Institut Pertanian Bogor.

Rimbing, J, V. Memah, dan M. F. Dien. 2007. Keanekaragaman Jenis dan Kelimpahan Musuh-Musuh Alami Sebagai Agens Pengendalian Hayati Pada Beberapa Habitat Pertanaman Kedelai Di Minahasa Utara. Fakultas Pertanian Unsrat. Manado.

J. Pelealu, dan R. Maramis. 2010. Penggunaan Jenis Pupuk dan Mulsa Jerami pada Tanaman Kedelai terhadap Serangan Penggerek Polong, Etiella zinckenella. Eugenia Volume 16 No. 3 Desember 2010.
Rohim, M. 1999. Pengaruh Kombinasi Mulsa dan Dosis Pupuk Nitrogen Pada Tanaman Kubis di Lahan Pasir Pantai. Skripsi S1. Universitas Wangsa Manggala Yogyakarta.

Sembel, D. T., J. Rimbing dan D. Tarore. 1989. Studi Pengendalian hama terpadu hamahama tanaman kedelai (Glycine max L. Merril) di Sulawesi Utara. Fakultas Pertanian Unsrat. Manado

J. Rimbing, D. Walalangi, M. Ratulangi, dan M. Meray. 2000. Pemantauan, Peramalan Serta Pengendalian Organisme Pengganggu Tanaman Pangan Di Sulawesi Utara. Fakultas Pertanian Unsrat. Manado.

Senewe, E., J. Rimbing, V. Memah, B. Assa, dan R. Engka. 2005. Kajian Pengembangan Produk Beras Organik Dalam Hubungan Dengan Organisme Pengganggu tanaman dan Musuh alami Pada Tanaman Padi Sawah Di Sulawesi Utara. Fakultas Pertanian Unsrat. Manado.

Simth, A.W. and R.B. Hammond. 1988. Influence of rye Cover Crop Management on Soybean Foliage Arthropods. Environ Entomol.

Sugiyarto dan Ending Anggarwulan. 2002. Pengaruh Pemuklsaan Berbagai Bahan Organik Sisa Tanaman Terhadap Produktivitas Jagung. Prosding Laokarya Nasional Pertanian organik. Malang 
Sugito, Y. 2002. Pembangunan Pertanian Berkelanjutan di Indonesia Prospek dan Permasalahannya. Memasyarakat Pertanian Organik Sebagai Jembatan Menuju Pembangunan Pertanian Berkelanjutan. Prosiding Lokakarya Nasional Pertanian Organik. Universitas Bawaijaya. Malang.

Surjana, T., J. Rachman Hidayat, dan Lily Purwati. 1993. Ketahanan Varietas Kedelai Terhadap Penggerek Polong Kedelai Etiella zinckenella di Lapangan. Balai Penelitian Tanaman Pangan, Bogor

Sutanto, R. 2000. Penerapan Pertanian Organik. Pemasyarakatan dan Pengembangan. Penerbit Kanisius, Yogyakarta.
Taroreh, D, 1995. Preferensi Penelusuran, Biologi dan Pengaruh Insektisida terhadap Populasi Riptortus Linearis F. (Hemiptera: Alydidae) pada Empat Varietas Unggul Kedelai di Kecamatan Dumoga Kabupaten Bolaang, Mongondow. IPB, Bogor

Wardani, N. 2001. Evaluasi Peranan Parasitoid dan Predator Telur Nezara viridula $L$ dan Piezodorus hybneri G (Hemiptera: Pentatomidae) di Pertanaman Kedelai. Tesis. Program Pascasarjana Institut Pertanian Bogor. 